Acta Regionalia et Environmentalica 1

Nitra, Slovaca Universitas Agriculturae Nitriae, 2018, pp. 5-9

\title{
TRENDS AND PERSPECTIVES OF FUELWOOD PRODUCTION IN EUROPE
}

\author{
Pavol OTEPKA ${ }^{1}$, Volodymyr GRYNENKO ${ }^{1,2}$ \\ ${ }^{1}$ Slovak University of Agriculture in Nitra, Slovak Republic \\ ${ }^{2}$ O.M. Beketov National University of Urban Economy in Kharkiv, Ukraine
}

\begin{abstract}
The paper focuses on the identification of trends and perspectives of fuelwood production in most countries of Europe. The shortages in forest territories per capita have been considered as forest poverty and the level of forest poverty has been measured. The indicator of fuelwood production intensity, which is defined as fuelwood production per hectare has been evaluated for every country under consideration. The EU countries have been classified by fuelwood production effectiveness and forest poverty. Trends of fuelwood production have been determined and the forecast of fuelwood production have been developed for selected countries.
\end{abstract}

Keywords: fuelwood production, EU, fuelwood production intensity, forest poverty

Wood fuel (or fuelwood) is a biofuel, such as firewood, charcoal, woodchips, wood sheets, wood pellets, and sawdust as well as a different mix of these materials. Fuelwood production is one of the significant components of renewable energy sector, which is one of determinants of sustainable development.

The aim of this paper is to identify current trends and to evaluate perspectives of fuelwood production in the European Union (EU). The tasks are to identify factors of fuelwood production, to evaluate how widely different countries use forest resources for fuelwood production and to assess perspectives of fuelwood production in the EU in general and in Slovakia in particular.

\section{Material and methods}

In this study, official Eurostat statistical data were used to analyse the situation with fuelwood production and forest resources. The data of EU on fuelwood production, import and export, forest resources and population were taken for every evaluated EU country during the long term period from 1992 to 2015 . The data on fuelwood are measured in thousands of cubic meters, and forest resources are given in hectares. To make the data comparable between different countries the indicators of forested area and fuelwood production were calculated per capita using countries population data.

The first step of the analysis was to evaluate forest resources availability in EU countries. Fuelwood production depends on forest resources availability; therefore, it is useful to evaluate which countries and how deeply are deprived of forests.
For the purpose of this evaluation, the index of forest poverty has been designed and evaluated. Poverty generally means deprivation, shortage in one or several basic essential needs (Kakwani and Silber, 2008; Nussbaum, 2000; Sen 1985; Atkinson and Bourguignon, 1999; Bossert, D'Ambrosio and Peragine 2007). Poverty is considered not only as income deprivation (income poverty) but also deprivation of any significant value or resource such as water (Jemmali, 2017), energy (Sadath and Acharya, 2017) etc.

The analysis of poverty requires defining the minimal poverty threshold (Alkire and Foster, 2011). Values (in our case forests area per capita) under this threshold are considered as poor, but the threshold itself is a matter of discussions (Ravallion, 2011). The poverty threshold used in the Organization for Economic Co-operation and Development $(\mathrm{OECD})$ and the EU is a level of income ordinarily established at $60 \%$ of the median household income, or individuals who fall into the bottom $20 \%$ of the income distribution might be considered as poor (Alkire and Foster, 2011). We decided to apply this criterion also for country-level forest poverty evaluation. Thus, we used $60 \%$ of EU average value of forest area per capita indicator as the threshold for identification of countries which are deprived of forests.

The level of poverty is measured as absolute or relative poverty gaps (Alkire and Foster, 2011). Absolute poverty gap is a difference between the factual value of any indicator and its poverty threshold in the case if this value is below the threshold. If the value is higher the poverty gap is considered to be equal to zero:

$$
\begin{gathered}
A F P G=\text { forests area per capita }- \text { forests } \\
\text { area per capita } \text { threshold }_{\text {if }} A F P G<0
\end{gathered}
$$


where:

AFPG - absolute forest poverty gap forests area per capita - factual value forests area per capita threshold $_{\text {- poverty }}$ as $60 \%$ EU aggregate for this indicator

Normalized (relative) forest poverty gap is a ratio of absolute poverty gap over its threshold:

$$
N F P G=\frac{-A F P G_{i}}{\text { forests area per capita } \text { threshold }_{\text {p }}}
$$

We calculated the absolute and normalized forest poverty gaps for all EU countries and ranked them according to the level of forest poverty. This way, the EU countries most deprived of forests were identified.

The following stage was to evaluate how intensively countries use available forest resources for fuelwood production. For this task a new index of fuelwood production intensity (FPI) was introduced into this research. We propose to evaluate this index as threshold, which is defined

the quantity of fuelwood produced annually in one hectare of forests:

$$
F P I=\frac{\text { fuelwood production, } \mathrm{m}^{3}}{\text { forests area, ha }}
$$

We also ranked EU countries according to this "new" indicator and identified the countries which use forests for fuelwood production the most and the least intensively.

A linear regression model was applied to identify determinants of the level of fuelwood production in the EU. The Pearson correlation coefficient was calculated for the tested indicators and t-tests were applied for hypotheses testing regarding significance of factors influence on fuelwood production. $T$-test critical value for $5 \%$ significance level is 2.069 .

All the operations with the data including extraction, cleaning, transformation, evaluation of indexes of forests poverty and fuelwood production intensity, ranking of EU countries and regression modelling were performed with Python scripts

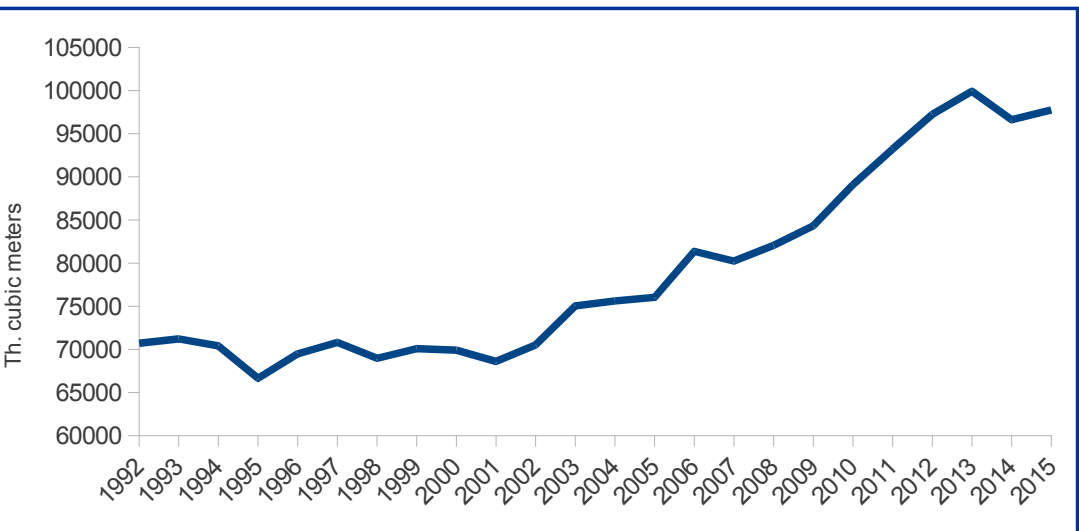

Figure 1 Fuelwood production in the European Union

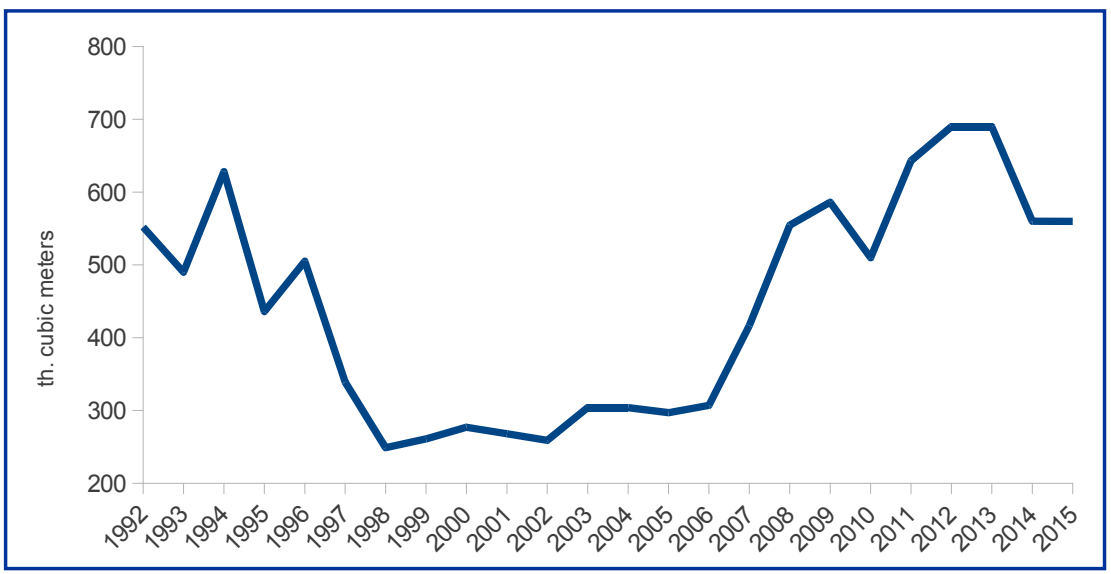

Figure 2 Fuelwood production in Slovakia using NumPy, Pandas and SciPy libraries. The scripts were coded specially for this research. The results of the analysis were used to produce qualitative forecast of fuelwood production in most of the EU countries with the major emphasis on Slovakia.

\section{Results and discussion}

The level of fuelwood production in the European Union has been growing since 2000 (Figure 1) and this source of energy has been becoming more and more important for European and Slovak economies.

Fuelwood production in Slovakia has experienced crisis in the recent years (Figure 2). The level of production has been decreased by about 30\% comparing to the peak years of 20122013. However, this crisis was general for all of the EU (see Figure 1) but, different to Slovakia, the EU as a whole has started to renew this industry.

The level of forest poverty was evaluated for the year 2015. There are 10 forest-deprived countries (Table 1) where the indicator of forests area per capita is below the poverty threshold ( $60 \%$ of the EU average level).

The highest NFPG value 0.12 corresponds to the country most deprived in forest resources (Malta).

Further, we ranked the EU and some neighbouring countries by the level of fuelwood production per capita and fuelwood production intensity (see Table 2). The majority of countries which are poor in forests have low levels of fuelwood production (less than the EU average). The only exception is Denmark, which is the leader in fuelwood production, despite the deficit of forests.

As for Slovakia, the country possesses large forest resources, but the actual level of fuelwood production is significantly lower than in close countries, such as the Czech Republic, Romania, Austria, Hungary or Bulgaria.

We found out that the leader in intensive production of fuelwood is Denmark, which is a deprived country in the sense of forest resources. The Netherlands and Germany also use their forest resources very intensively. The position of Slovakia corresponds 
to the countries with large areas of forests, such as Latvia, Finland, Norway or Sweden.

In general, it can be said that the level of fuelwood production depends on availability of forest resources, but forest resource itself is less significant than policies in the sphere of energetics. Economically developed countries which are interested in renewable energy usage growth, such as Denmark, Germany, and the Netherlands became the leaders of fuelwood production and use. And, in contrast, many countries rich in forests still underrate their own potential in this sphere.

Therefore, fuelwood production in the EU has a high potential of growth on the account of countries with underused forest resources. The level of fuelwood production is limited not by forests resource availability,
Table 1 Forest poverty in the EU countries, normalized forest poverty gaps (NFPG)

\begin{tabular}{|l||c|c|}
\hline Rank & Country & NFPGs, 2015 \\
\hline \hline $\mathbf{1}$ & Malta & 0.12 \\
\hline $\mathbf{2}$ & Netherlands & 0.11 \\
\hline $\mathbf{3}$ & United Kingdom & 0.09 \\
\hline $\mathbf{4}$ & Belgium & 0.08 \\
\hline $\mathbf{5}$ & Denmark & 0.05 \\
\hline $\mathbf{6}$ & Germany & 0.03 \\
\hline $\mathbf{7}$ & Cyprus & 0.03 \\
\hline $\mathbf{8}$ & Luxembourg & 0.02 \\
\hline $\mathbf{9}$ & Italy & 0.02 \\
\hline $\mathbf{1 0}$ & Ireland & 0.02 \\
\hline
\end{tabular}

Table 2 Fuelwood production per capita and fuelwood intensity index

\begin{tabular}{|c|c|c|c|c|c|}
\hline \multicolumn{3}{|c|}{ Fuelwood production per capita, 2015} & \multicolumn{3}{|c|}{ Fuelwood production intensity index, 2015} \\
\hline Rank & country & cubic meters per capita & Rank & country & cubic meters per hectare of forests \\
\hline 1 & Estonia & 1.84 & 1 & Denmark & 3.24 \\
\hline 2 & Finland & 1.42 & 2 & France & 1.60 \\
\hline 3 & Lithuania & 0.80 & 3 & Hungary & 1.39 \\
\hline 4 & Sweden & 0.62 & 4 & Switzerland & 1.33 \\
\hline 5 & Latvia & 0.61 & 5 & Austria & 1.28 \\
\hline 6 & Austria & 0.59 & 6 & Lithuania & 1.12 \\
\hline 7 & Slovenia & 0.55 & 7 & Estonia & 1.09 \\
\hline 8 & Norway & 0.52 & 8 & Germany & 0.98 \\
\hline 9 & France & 0.41 & 9 & Slovenia & 0.90 \\
\hline 10 & Bulgaria & 0.37 & 10 & Czech Republic & 0.82 \\
\hline 11 & Denmark & 0.34 & 11 & Netherlands & 0.77 \\
\hline 12 & Croatia & 0.33 & 12 & Romania & 0.76 \\
\hline 13 & Hungary & 0.29 & 13 & Croatia & 0.73 \\
\hline 14 & Romania & 0.25 & 14 & Bulgaria & 0.73 \\
\hline 15 & Switzerland & 0.21 & 15 & Liechtenstein & 0.71 \\
\hline 16 & Czech Republic & 0.21 & 16 & European Union & 0.62 \\
\hline 17 & European Union & 0.20 & 17 & Italy & 0.59 \\
\hline 18 & Germany & 0.14 & 18 & Poland & 0.55 \\
\hline 19 & Poland & 0.13 & 19 & United Kingdom & 0.51 \\
\hline 20 & Liechtenstein & 0.13 & 20 & Latvia & 0.38 \\
\hline 21 & Slovakia & 0.13 & 21 & Slovakia & 0.36 \\
\hline 22 & Spain & 0.07 & 22 & Finland & 0.34 \\
\hline 23 & Greece & 0.07 & 23 & Ireland & 0.28 \\
\hline 24 & Portugal & 0.06 & 24 & Norway & 0.21 \\
\hline 25 & Ireland & 0.05 & 25 & Sweden & 0.21 \\
\hline 26 & Luxembourg & 0.03 & 26 & Luxembourg & 0.19 \\
\hline 27 & United Kingdom & 0.02 & 27 & Greece & 0.19 \\
\hline 28 & Netherlands & 0.02 & 28 & Portugal & 0.19 \\
\hline 29 & Italy & 0.01 & 29 & Spain & 0.19 \\
\hline 30 & Cyprus & 0.01 & 30 & Cyprus & 0.03 \\
\hline 31 & Malta & 0.00 & 31 & Malta & 0.00 \\
\hline
\end{tabular}


Table 3 Fuelwood production level changes in 2014/2015 by countries in thousands of cubic meters

\begin{tabular}{|c|c|c|c|c|}
\hline Country & 2014 & 2015 & growth & $\%$ \\
\hline European Union (28 countries) & 96,617 & 97,745 & 1,128 & 1 \\
\hline Bulgaria & 2,534 & 2,848 & 315 & 12 \\
\hline Czech Republic & 2,111 & 2,336 & 225 & 11 \\
\hline Germany & 11,114 & 10,494 & -620 & -6 \\
\hline Estonia & 2,257 & 2,179 & -78 & -3 \\
\hline Ireland & 206 & 203 & -3 & -2 \\
\hline Spain & 3,709 & 3,709 & 0 & 0 \\
\hline France & 26,116 & 25,962 & -154 & -1 \\
\hline Croatia & 2,300 & 1,769 & -532 & -23 \\
\hline Italy & 3,717 & 3,004 & -713 & -19 \\
\hline Cyprus & 5 & 7 & 3 & 55 \\
\hline Latvia & 1,299 & 1,200 & -99 & -8 \\
\hline Lithuania & 2,316 & 2,110 & -206 & -9 \\
\hline Netherlands & 4 & 357 & 353 & 9,549 \\
\hline Austria & 5,059 & 4,979 & -80 & -2 \\
\hline Poland & 5,185 & 5,152 & -33 & -1 \\
\hline Portugal & 600 & 600 & 0 & 0 \\
\hline Romania & 4,859 & 5,079 & 220 & 5 \\
\hline Slovenia & 1,589 & 1,242 & -346 & -22 \\
\hline Slovakia & 560 & 560 & 0 & 0 \\
\hline Finland & 7,832 & 7,964 & 133 & 2 \\
\hline Sweden & 5,900 & 7,000 & 1,100 & 19 \\
\hline United Kingdom & 1,823 & 1,921 & 98 & 5 \\
\hline Liechtenstein & 5 & 4 & -1 & -25 \\
\hline Norway & 1,568 & 1,718 & 150 & 10 \\
\hline Switzerland & 1,643 & 1,584 & -59 & -4 \\
\hline
\end{tabular}

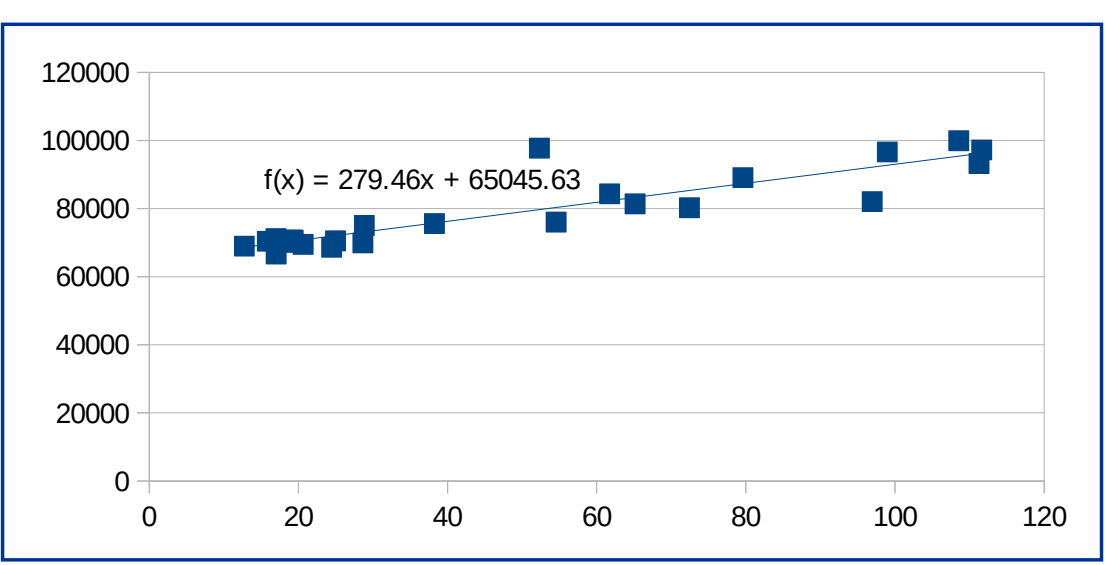

Figure 3 Regression analysis of fuelwood production in EU in thousands cubic meters on oil prices taken from the Brent Spot Price FOB (US dollars per one Barrel) but by socio-economic factors which determine the demand on this kind of fuel.

The regression analysis showed that the main determinant of fuelwood production in the $\mathrm{EU}$ is the price of oil (Figure 3). The analysis is based on annual data for the period 1992-2015. Parameters of the model are the following: $R^{2}=0.7943335617$, standard error $=5,090.301069663$, Pearson correlation coefficient $=0.8912539266$, $t$-statistics $=-35.3315295168$. The model demonstrates that the crisis of fuelwood production in the years of 2014-2015 is predetermined by oil prices drop from about a hundred USD per barrel to 50 USD per barrel what decreased competitiveness of wood as a fuel. 
The fuelwood production level of 2015, the last year of observation is an outlier in this model, since the level of fuelwood production has started to recover because of the low oil prices. To explain it, deeper view on fuelwood production level change is needed.

Only the countries, for which the data of 2015 is available, are included in the Table 3. The data showed that the level of fuelwood production in the majority of countries decreased, and this is in full correspondence to the oil prices model. Only a few countries demonstrated growth. These are not connected with forest poverty, with large forest resources and with relatively low level of fuelwood production intensity (see Tables 1-2). The countries of intensive fuelwood production, particularly those with forest poverty like Germany have shortened this industry. The only exception is the Netherlands with limited forest areas, but this country also has relatively low fuelwood production intensity index. The Netherlands almost stopped fuelwood production in the year of oil prices drop (2014), but afterwards restored it. All the countries which produced more than 0.9 cubic meter of fuelwood per hectare of forest area have shortened fuelwood production in 2015.

We consider that this dynamics may be explained by the higher costs of intensive fuelwood production technologies, like planting trees, forest cut specially for energy purposes while low intensive fuelwood production may be relatively cheaper (like usage of different available wood wastes). High costs could be covered in the condition of high fuel prices, but it became impossible after fuel prices drop. In contrast, cheap fuelwood may still meet its demand.

Fuelwood production forecast is on one hand limited by demand, which depends on fuel prices, but, on the other hand, it has a high potential of growth in the countries with large forest resources and with low fuelwood production intensity, where cheap wood raw materials are available for fuelwood producers. Slovakia meets these conditions. This is the country with large forests which are, due to statistics, almost not used for fuelwood production. The highest value of fuelwood production intensity index was 0.36 cubic meter of fuelwood per hectare in the peak year of 2013, but in 2014 and 2015, the country experienced a decrease of this indicator to 0.29 cubic meter of fuelwood per hectare. At the same time, the Czech Republic has already overcome the crisis and reached the fuelwood production intensity level of 0.88 . The Hungarian data of 2015 is absent, but fuelwood production there was growing even in the crisis year of 2014. Similar situation is also in Romania with fuelwood production intensity index values $0.76,0.72,0.74$ in 2013-2015, respectively.

Thus, actual situation with fuelwood production in Slovakia is controversial. The country has all prerequisites for fuelwood production growth, but there is no growth according to the Eurostat data. At the same time, fuelwood production is much higher and is growing in neighbouring countries with similar socio-economic and environmental conditions. Now, fuelwood production in Slovakia fluctuates together with oil prices and may grow significantly only if these prices grow what is unexpected in the next few years. But, objectively, the country may double or triple the level of fuelwood production even with low oil prices and reach the level of fuelwood production intensity of neighbouring countries if to eliminate invisible factors which prevent growth.

\section{Conclusion}

Fuelwood is an important component of renewable energy sector and its production has a trend to grow in Europe since the beginning of the century. Now, this industry is in crisis caused by the decrease of oil prices after the year of 2014 and the majority of European countries decreased the level of fuelwood production.

It is shown with the indices of forest poverty and fuelwood production intensity that fuelwood production continues to grow only in the countries with large forests and with low intensity of production, and we consider that this growth is caused by low costs of fuelwood production in the conditions of availability of wood raw materials.

Therefore, only the countries which meet the conditions of forests availability and low intensity of fuelwood production such as Slovakia have perspectives of fuelwood production growth with current low fuel prices.

\section{Acknowledgements}

The work has been supported by the National Scholarship Programme of the Slovak Republic and by the project No.: IEE/10/470/SI2.593725 "Promotion to Regional Bioenergy Initiatives - PromoBio", implemented within the EU program "Intelligent Energy - Europe".

\section{References}

ALKIRE, S. - FOSTER, J. 2011. Understandings and misunderstandings of multidimensional poverty measurement. In The Journal of Economic Inequality, vol. 9, 2011, pp. 289-314. DOI: 10.1007/s10888-011-9181-4.

ATKINSON, A.B. - BOURGUIGNON, F. 1999. Poverty and inclusion from a world perspective. In Paper presented for the ABCDE Europe conference, Paris, 1999, $16 \mathrm{p}$.

BOSSERT, W. - D'AMBROSIO, C. - PERAGINE, V. 2007. Deprivation and social exclusion. In Economica, vol. 74, 2007, no. 296, pp. 777-803.

JEMMALI, H. 2017. Mapping water poverty in Africa using the improved Multidimensional Index of Water Poverty. In International Journal of Water Resources Development, vol. 33, 2017, no. 4, pp. 649-666.

KAKWANI, N. - SILBER, J. 2008. Introduction: multidimensional Poverty analysis: Conceptual Issues, Empirical Illustrations and Policy Implications. In World Development, vol. 36, 2008, pp. 987991. DOI: 10.1016/j.worlddev.2007.10.004.

NUSSBAUM, M.C. 2000. Women and human development: The capabilities approach. Cambridge University Press, 2000.

RAVALLION, M. 2011. On multidimensional indices of poverty. In The Journal of Economic Inequality, vol. 9, 2011, pp. 235-248. DOI: 10.1007/s10888-011-9173-4.

SADATH, A.C. - ACHARYA, R.H. 2017. Assessing the extent and intensity of energy poverty using Multidimensional Energy Poverty Index: Empirical evidence from households in India. In Energy Policy, vol. 102, 2017, pp. 540-548.

SEN, A. 1985. Commodities and capabilities. Amsterdam : NorthHolland, 1985, 102 p. 